\title{
Receptors and Growth-promoting Effects of Insulin and Insulinlike Growth Factors on Cells from Bovine Retinal Capillaries and Aorta
}

\author{
George L. King, A. David Goodman, Sheldon Buzney, Alan Moses, and C. Ronald Kahn \\ Research Division, Joslin Diabetes Center, Boston, Massachusetts 02215; Department of Medicine, Brigham and Women's Hospital, \\ and Harvard Medical School, Boston, Massachusetts 02115; Department of Medicine, Albany Medical College, Albany, New York \\ 12208; Eye Research Institute of Retina Foundation, Boston, Massachusetts 02114; Department of Medicine, Beth Israel Hospital, \\ Boston, Massachusetts 02215; Harvard Medical School, Boston, Massachusetts 02115
}

\section{Abstract}

It has been suggested that elevated levels of insulin or insulinlike growth factors (IGFs) play a role in the development of diabetic vascular complications. Previously, we have shown a differential response to insulin between vascular cells from retinal capillaries and large arteries with the former being much more insulin responsive. In the present study, we have characterized the receptors and the growth-promoting effect of insulinlike growth factor I (IGF-I) and multiplication-stimulating activity (MSA, an IGF-II) on endothelial cells and pericytes from calf retinal capillaries and on endothelial and smooth muscle cells from calf aorta.

We found single and separate populations of high affinity receptors for IGF-I and MSA with respective affinity constants of $1 \times 10^{-9} \mathrm{M}^{-1}$ and $10^{-8} \mathrm{M}^{-1}$ in all four cell types studied. Specific binding of IGF-I was between 7.2 and $7.9 \%$ per milligram of protein in endothelial cells and 9.1 and $10.4 \%$ in the vascular supporting cells. For ${ }^{125} \mathrm{I}-\mathrm{MSA}$, retinal endothelial cells bound only $1.7-2.5 \%$, whereas the aortic endothelial cells and the vascular supporting cells bound between 5.6 and $8.5 \%$ per milligram of protein. The specificity of the receptors for IGF-I and MSA differed, as insulin and MSA was able to compete with ${ }^{125}$ I-IGF-I for binding to the IGF-I receptors with $0.01-0.1$, the potency of unlabeled IGF-I, whereas even $1 \times 10^{-6} \mathrm{M}$, insulin did not significantly compete with ${ }^{125} \mathrm{I}-$ MSA for binding to the receptors for MSA.

For growth-promoting effects, as measured by the incorporation of $\left[{ }^{3} \mathrm{H}\right]$ thymidine into DNA, confluent retinal endothelial cells responded to IGF-I and MSA by up to threefold increase in the rate of DNA synthesis, whereas confluent aortic endothelial cells did not respond at all. A similar differential of response to insulin between micro- and macrovascular endothelial cells was reported by us previously. In the retinal endothelium, insulin was more potent than IGF-I and IGF-I was more potent that MSA.

In the retinal and aortic supporting cells, no differential response to insulin or the IGFs was observed. In the retinal pericytes, IGF-I, which stimulated significant DNA synthesis beginning at $1 \times 10^{-9} \mathrm{M}$, and had a maximal effect at 5 $\times 10^{-8} \mathrm{M}$, was 10 -fold more potent than MSA and equally

Dr. Moses is a Capps Fund Diabetes Scholar of Harvard Medical School. Dr. King is supported by a Research Development Award from the American Diabetes Association.

Received for publication 9 April 1984 and in revised form 30 October 1984.

J. Clin. Invest.

(c) The American Society for Clinical Investigation, Inc.

0021-9738/85/03/1028/09 \$1.00

Volume 75, March 1985, 1028-1036 potent to insulin. In the aortic smooth muscle cells, IGF-I was 10-100 times more potent than insulin or MSA. In addition, insulin and IGF-I at $1 \times 10^{-6}$ and $1 \times 10^{-8} \mathrm{M}$, respectively, stimulated these cells to grow by doubling the number of cells as well. In all responsive tissues, the combination of insulin and IGFs at submaximal concentrations showed an additive growth effect. However, when maximal concentrations of insulin and IGFs were added together, no further increase in effect was seen.

These data showed that vascular cells have insulin and IGF receptors, but have a differential response to these hormones. These differences in biological response between cells from retinal capillaries and large arteries could provide clues to understanding the pathogenesis of diabetic micro- and macroangiopathy.

\section{Introduction}

Proliferative retinopathy is one of the most common and serious vascular complications of diabetes, leading to blindness in $50 \%$ of patients within $5 \mathrm{yr}$ (1). The major pathological finding in the eye is neovascularization, which is the proliferation of retinal capillary endothelial cells (2). The factors that are responsible for neovascularization are not known, but growth hormone and its proposed mediators, the somatomedins, have been suggested to play a role $(3,4)$. Growth hormonedeficient dwarfs have glucose intolerance, but do not develop retinopathy (5), and severe proliferative retinopathy appears to be ameliorated in some patients by pituitary ablation (3). Recently, Lamberton et al. also reported that one of the somatomedins, insulinlike growth factor I (IGF-I), ${ }^{1}$ is elevated in some diabetic patients with advanced proliferative retinopathy (4), although the IGFs are not increased in diabetic patients with proliferative retinopathy as a whole (6).

Even though tissues involved in diabetic complications have generally been regarded as nonhormonally dependent, we recently demonstrated that endothelial cells and supporting cells of both large and small blood vessels possess insulin receptors and are insulin responsive (7). In the present study, we have characterized the receptors of IGF-I and multiplicationstimulating activity (MSA, a rat IGF-II) and growth-promoting effects of these growth factors in addition to growth hormone on cultured endothelial cells from bovine retinal capillaries and aorta, and on the supporting cells of these vessels; namely, the retinal capillary pericytes and aortic smooth muscle cells. We have also compared the effect of these hormones to those of insulin in the same tissues.

1. Abbreviations used in this paper: DMEM, Dulbecco's modified Eagle's medium; IGF, insulinlike growth factor(s); IGF-I and IGF-II, insulinlike growth factors I and II; MSA, multiplication-stimulating activity. 


\section{Methods}

Porcine insulin was purchased from Elanco Products Co., Indianapolis, IN. Pure IGF-I, isolated from human plasma by procedures as described previously, was a generous gift of Professor Rene E. Humbel (Biochemisches Institut der Universität, Zürich, Switzerland) (8). MSA was purified from conditioned media harvested from cultured cell lines of Buffalo rat liver cells, as previously described (9). Bovine growth hormone was kindly provided by Dr. Leo Reichert at the National Institutes of Health (NIH GH B18). $\mathrm{Na}^{125}$ I was obtained from New England Nuclear, Boston, MA. All other chemicals were of analytical grade and obtained from the Sigma Chemical Co., St. Louis, MO.

Iodination. Porcine insulin was iodinated by the lactoperoxidase method and the four monoiodoisomers were separated by high performance liquid chromatography on a reverse-phase column, as described previously (10). The isomer labeled on the 14 tyrosyl residue of the A chain of the insulin molecule (specific activity of $360 \mu \mathrm{Ci} / \mathrm{ug}$ ) was used as the tracer in all subsequent studies. Previous studies have shown that this isomer is indistinguishable from native insulin in its affinity for the insulin receptor and its bioactivity (11).

Both IGF-I and MSA III-2 were labeled by the modified chloramine T method and separated away from ${ }^{125}$ I and aggregated IGFs on a G50 column (12). The specific radioactivity of both the ${ }^{125}$ I-IGF-I and ${ }^{125} \mathrm{I}-\mathrm{MSA}$ used for the present studies ranged from 50 to $150 \mu \mathrm{Ci} / \mathrm{ug}$.

Cell cultures. Retinal capillary endothelial cells and pericytes were harvested from calf retinal capillaries, as described previously (7, 12). Briefly, retinas were dissected from newborn calves and homogenized in phosphate-buffered saline (PBS), $\mathrm{pH}$ 7.4. The mixture was filtered sequentially through nylon screen meshes with pore sizes ranging from 88 to $53 \mu \mathrm{M}$. Retinal capillaries retained by the last nylon screen were incubated in PBS, containing $0.75 \%$ collagenase (Worthington Biochemical Corp., Freehold, NJ) and $0.5 \%$ bovine serum albumin (Sigma Chemical Co.), for $30 \mathrm{~min}$ at $37^{\circ} \mathrm{C}$. Bovine vascular cells and partially digested capillaries were collected by centrifugation and cultured on gelatin-coated tissue culture dishes (Costar, Data Packaging, Cambridge, MA). Endothelial cells were cultured in conditioned Dulbecco's modified Eagle's medium (DMEM) with penicillin, $200 \mathrm{U} / \mathrm{ml}$, and $10 \%$ calf serum (Gibco Laboratories, Grand Island, NY). The DMEM had been previously conditioned by being incubated with mouse sarcoma 180 tumor cells for $48 \mathrm{~h}$ at $37^{\circ} \mathrm{C}$ under growth conditions (12). For pericytes, "conditioned" DMEM with $20 \%$ calf serum was used. The sarcoma conditioned media was used because it promotes the growth of retinal endothelial cells.

2-3 d after plating, either the endothelial or support cells were identified under a phase-contrast microscope and the unwanted cell type as defined by morphology was removed using a finely tapered Pasteur pipette attached to a micromanipulator (Brinkmann Instruments, Inc., Westbury, NY) as described by Folkman et al. (13). This "weeding" procedure was performed daily until pure cultures were obtained. The cells were then harvested by treatment with $1 \mathrm{ml}$ of $0.05 \%$ trypsin (Sigma Chemical Co.), with $0.2 \%$ EDTA (Gibco Laboratories) for 3 min.

Calf aortic endothelial cells were isolated as described previously (7). Briefly, the intimal aspect of calf aorta was exposed and incubated in $0.1 \%$ collagenase (Worthington Biochemical Corp.) for $30 \mathrm{~min}$ at room temperature. The aorta was washed with PBS and gently scraped once with a cotton swab, and the cells on the swab were plated in culture dishes. Weeding procedures were necessary to isolate and purify endothelial cells from contaminating smooth muscle cells as described above, except that the aortic endothelial cells were grown in DMEM media with $10 \%$ calf serum (Gibco Laboratories). Aortic endothelial cells used for DNA synthesis studies were also grown in sarcomaconditioned DMEM. No difference was found in the hormonal responsiveness of endothelial cells grown in the presence and absence of sarcoma-conditioned media.

Aortic smooth muscle cells were harvested from calf aorta using a modification of the procedures as Gimbrone et al. (14). The cells were initially removed from the medial section of the aorta by dissection.
The explants were set in a Costar culture dish in DMEM media with $10 \%$ calf serum. After the cells had covered the bottom of the plate, they were incubated with $0.1 \%$ trypsin for $4 \mathrm{~min}$ and loose cells were rinsed from the plates. The smooth muscle cells were then passaged in 1:3 ratio. Cells between 1 and 10th passages were used for these studies.

Cell identification. The identity of the cells was confirmed by morphologic criteria with phase-contrast microscopy. In addition, all the cells were examined for the presence of Factor VIII using indirect immunofluorescence with a monospecific bovine Factor VIII antibody, a gift of J. Brown, University of California, San Diego (7). Angiotensinconverting enzyme activity in cultured cells was determined using a radioassay (Ventrex, Portland, ME). The endothelial cells from the retinal capillary and the aorta were positive for Factor VIII and angiotensin-converting enzyme activity, whereas pericytes and smooth muscle cells were not. By using these biochemical and morphological tests, the cultures were determined to be free of contaminating cells.

Autoradiography. Cells were seeded to 50\% of confluency and maintained for $24 \mathrm{~h}$ in DMEM media with $0.5 \%$ bovine serum. Hormones were added for $20 \mathrm{~h}$, followed by $\left[{ }^{3} \mathrm{H}\right]$ thymidine (New England Nuclear) for $24 \mathrm{~h}$. The procedure for fixing and developing have been described (15).

Binding studies. ${ }^{125} \mathrm{I}$-insulin, ${ }^{125} \mathrm{I}-\mathrm{IGF}$, or ${ }^{125} \mathrm{I}$-MSA binding studies were performed on cells attached to $35-\mathrm{mm}$ six-well plates $(\sim 50,000$ cpm to each well) as described earlier $(7,16)$. Incubation was at $15^{\circ} \mathrm{C}$ for $4 \mathrm{~h}$ in $0.1 \mathrm{M}$ Hepes binding buffer, $\mathrm{pH} 7.8$, containing $0.12 \mathrm{M}$ $\mathrm{NaC}_{1}, 5 \mathrm{mM} \mathrm{KCl}, 1.2 \mathrm{mM} \mathrm{Mg} \mathrm{SO}, 8 \mathrm{mM}$ glucose, and $1 \%$ bovine serum albumin. Concentrations of labeled and unlabeled insulin, IGFI, and MSA were added as noted in the figures. After binding, the cells were washed with $\mathrm{PBS}$ at $4^{\circ} \mathrm{C}$ and solubilized with $0.1 \%$ sodium dodecyl sulfate. The samples were counted in Tracor 1190 gamma counter (Tracer Analytic Inc., Elk Village, IL) at $80 \%$ efficiency.

Protein assays were performed by the method of Lowry et al. (17) with bovine albumin as standard. (7).

$\left[{ }^{3} \mathrm{H}\right]$ Thymidine incorporated into DNA. Cells were grown to near confluence at $37^{\circ} \mathrm{C}$ in six-well cluster plates (Costar). The growth media was replaced with serum-free DMEM medium, $\mathrm{pH} 7.4$, containing $2.5 \mathrm{mg} / \mathrm{ml}$ bovine serum albumin and $0.5 \%$ of bovine serum for 1-2 d. Insulin, IGF-I, or MSA were added to each well with fresh serum-free DMEM media at the indicated concentrations for $18 \mathrm{~h}$, after which the cells were pulsed with $\left[{ }^{3} \mathrm{H}\right]$ thymidine, $2 \mu \mathrm{Ci} / \mathrm{ml}$, for 30 min at $37^{\circ} \mathrm{C}$. The cells were solubilized with $0.1 \%$ sodium dodecyl sulfate, and the DNA precipitated with $10 \%$ trichloracetic acid at $4^{\circ} \mathrm{C}$ and counted in a scintillation counter as previously described $(15,16)$.

Cell number count. Cells were grown in 12-well cluster dishes (Costar) as discussed above and released from the plate by 0.1 trypsin in PBS. The cell number was determined by Coulter counters in triplicate.

\section{Results}

\section{IGF-I receptor studies}

Endothelial cells. Using ${ }^{125}$ I-IGF-I in competition studies (Fig. 1), high affinity IGF-I receptors were identified on both retinal capillary and aortic endothelial cells. Specific binding of tracer was similar for aortic and retinal endothelial cells $(7.2$ vs. $7.9 \%$ bound per milligram of protein). $50 \%$ of the ${ }^{125}$ I-IGF-I that was specifically bound was displaced by 1 and $3 \times 10^{-9} \mathrm{M}$ of unlabeled IGF-I, respectively, on aortic and retinal capillary endothelial cells. MSA and insulin also competed with IGF-I for binding. However, MSA was 100 -fold less potent than IGF-I in both cell types, and insulin was $1 / 100$ th as potent on aortic endothelial cells, and only $1 / 1,000$ th as potent as IGF-I on retinal endothelial cells. Scatchard analysis of IGF-I binding, as illustrated in Fig. $2 \mathrm{~A}$, yielded straight lines for both microand macrovascular endothelial cells, suggesting a uniform population of IGF-I receptors (18). The derived apparent 

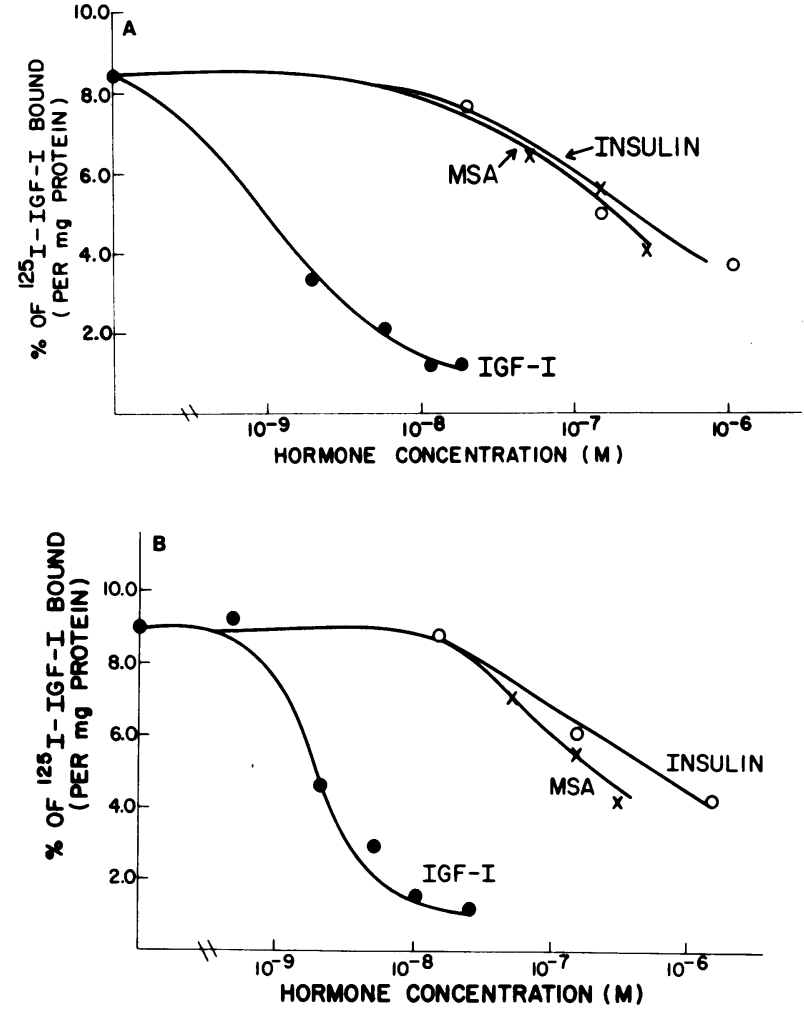

Figure 1. Inhibition of ${ }^{125}$ I-IGF-I binding to $(A)$ aortic and $(B)$ retinal capillary endothelial cells by unlabeled IGF-I $(\bullet)$, MSA $(X)$, and insulin (O). Each point is the average of duplicates in one experiment. Conditions of the binding are described in Methods.

equilibrium constants were $1.4 \times 10^{-9} \mathrm{M}$ and $1.8 \times 10^{-9} \mathrm{M}^{-1}$, respectively, for aortic and retinal capillary endothelial cells, indicating high affinity IGF-I receptors (Table I).

Vascular supporting cells. The specific binding of ${ }^{125} \mathrm{IGF}-\mathrm{I}$ to the vascular supporting cells was higher than the endothelial cells. The specific binding of ${ }^{125} \mathrm{I}-\mathrm{IGF}-\mathrm{I}$ to aortic smooth muscle cells and retinal capillary pericytes was $10.4 \%$ and $9.1 \%$ per milligram of protein, respectively (Fig. 3, A and B). For aortic smooth muscle cells, $50 \%$ of ${ }^{125} \mathrm{I}$-IGF-I binding was displaced by $\sim 1.5 \times 10^{-9} \mathrm{M}$ of unlabeled IGF-I, indicating high affinity IGF-I receptors. Unlabeled insulin also inhibited ${ }^{125}$ I-IGF-I binding, but was $<1 \%$ as potent. In addition, a slight increase of ${ }^{125} \mathrm{I}-\mathrm{IGF}$-I binding was observed when $2 \times 10^{-9} \mathrm{M}$ of insulin was added. With retinal pericytes, IGF-I at $1 \times 10^{-9} \mathrm{M}$ inhibited ${ }^{125}$ I-IGF-I binding by at least $50 \%$. Again, insulin was 100 -fold less potent than IGF-I in competing with ${ }^{125} \mathrm{I}-\mathrm{IGF}-\mathrm{I}$ for binding. However, at $1 \times 10^{-6} \mathrm{M}$ of insulin, $70 \%$ of the specifically bound ${ }^{125} \mathrm{I}$-IGF-I on retinal pericytes was displaced in contrast to only $40 \%$ in aortic smooth muscle cells.

The effect of MSA on retinal pericytes was examined. Similar to endothelial cells, MSA was $<10 \%$ as potent as IGFI in displacing ${ }^{125} \mathrm{I}-\mathrm{IGF}-\mathrm{I}$. Scatchard analysis of ${ }^{125} \mathrm{I}-\mathrm{IGF}-\mathrm{I}$ competition studies yielded straight lines similar to those of endothelial cells. The apparent $K_{\mathrm{d}}$ calculated from the slopes were $1 \times 10^{-9} \mathrm{M}^{-1}$ and $2 \times 10^{-9} \mathrm{M}^{-1}$ for aortic smooth muscle cells and retinal capillary pericytes, respectively (Table I).

$M S A$ receptor studies

Endothelial cells. It was found that the specific binding of ${ }^{125} \mathrm{I}$ MSA was at least $8.5 \%$ per milligram of protein in aortic
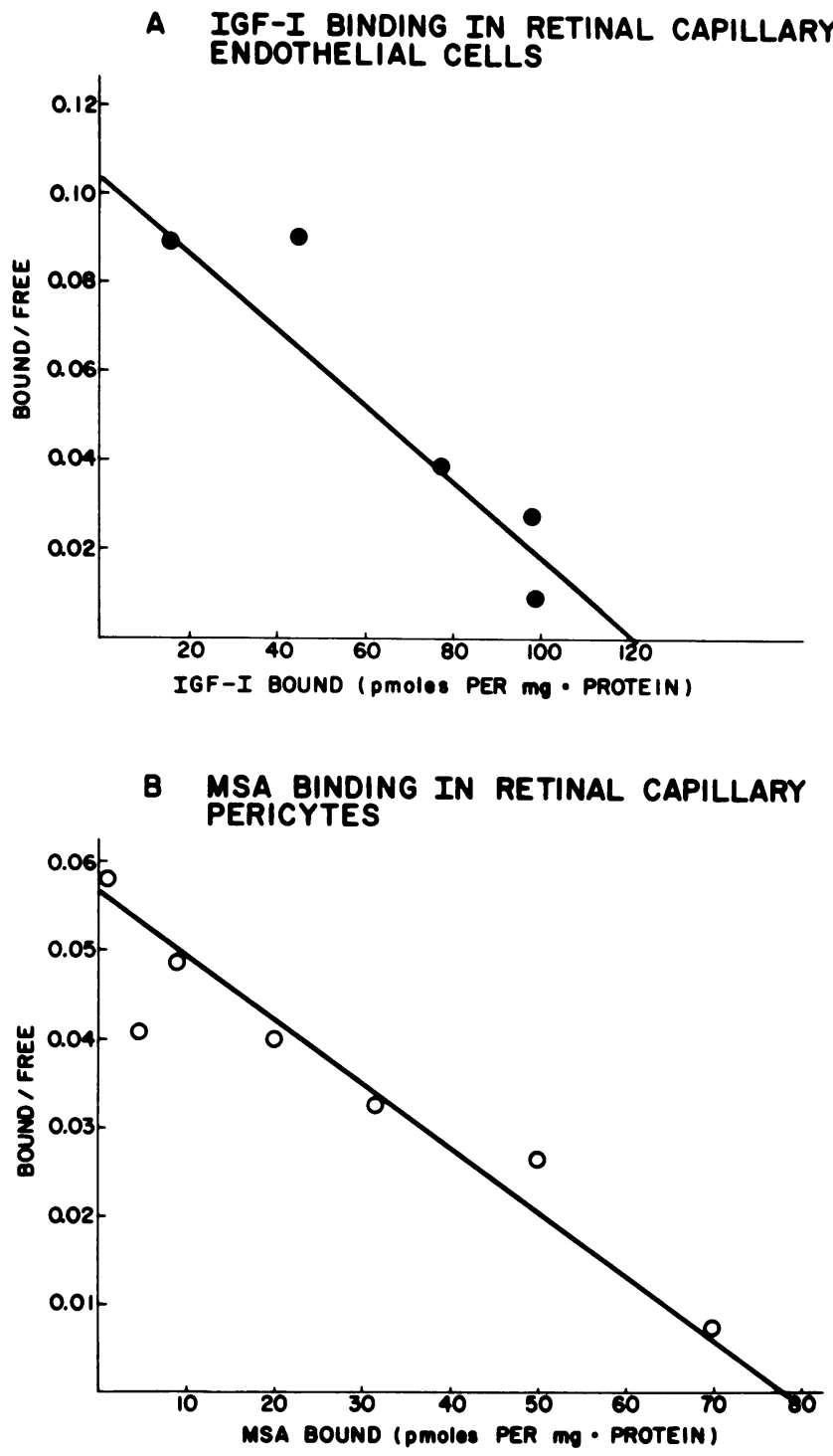

Figure 2. Scatchard analysis of $(A)^{125}$ I-IGF-I binding to retinal capillary endothelial cells and $(B){ }^{125}$ I-MSA binding to retinal capillary pericytes. The plot in $A$ was derived from the binding study of retinal endothelial cells in Fig. $1 B$. The plot for ${ }^{125} \mathrm{I}-\mathrm{MSA}$ binding was calculated from the study as shown in Fig. $5 \mathrm{~B}$. For calculations of the Scatchard plots, the bindings in the presence of the highest concentration of unlabeled IGF-I $(A)$ and MSA $(B)$ are assumed to be the nonspecific binding.

Table I. Equilibrium Constant (K) for IGF-I and MSA Binding Calculated from Scatchard Plot

\begin{tabular}{lll}
\hline Cell type & IGF-I* & MSA \\
\hline *Aortic endothelial cells & $1.4 \times 10^{-9} \mathrm{M}^{-1}$ & $1.0 \times 10^{-8} \mathrm{M}^{-1}$ \\
$\ddagger$ Retinal endothelial cells & $1.8 \times 10^{-9} \mathrm{M}^{-1}$ & $1 \times 10^{-8} \mathrm{M}^{-1}$ \\
Smooth muscle cells & $1.0 \times 10^{-9} \mathrm{M}^{-1}$ & $1.0 \times 10^{-8} \mathrm{M}^{-1}$ \\
Pericytes & $2.0 \times 10^{-9} \mathrm{M}^{-1}$ & $1.2 \times 10^{-8} \mathrm{M}^{-1}$
\end{tabular}

* Average of two experiments. Variation between experiments in all cells is not $>10 \%$.

$\ddagger$ Confluent cells were used and cultured as described in Methods. 

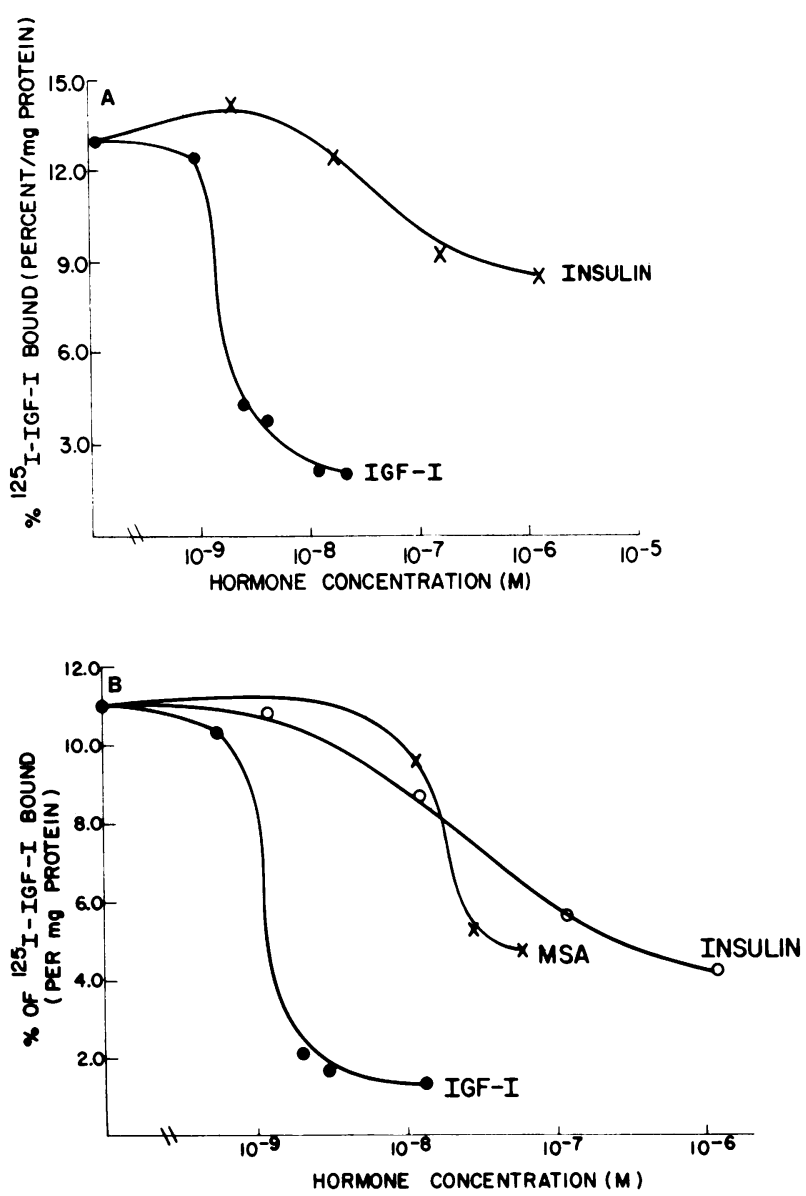

Figure 3. Inhibition of ${ }^{125}$ I-IGF-I binding to $(A)$ aortic smooth muscle cells and $(B)$ retinal capillary pericytes by unlabeled IGF-I, MSA and insulin. Each point is the average of duplicates in one experiment. Conditions for binding are as described in Methods.

endothelial cells (Fig. $4 \mathrm{~A}$ ), but only $1.7-2.5 \%$ in the retinal capillary endothelium (Fig. 4 B). $1-5 \times 10^{-8} \mathrm{M}^{-1} \mathrm{MSA}$ decreased total ${ }^{125}$ I-MSA binding by $50 \%$ in both types of cells, and in both cells insulin did not cause any displacement of ${ }^{125} \mathrm{I}-\mathrm{MSA}$, even at $10^{-6} \mathrm{M}$. Scatchard analysis showed straight lines for both aortic and retinal endothelial cells, and the $K_{d}$ value in both cell types was $1 \times 10^{-8} \mathrm{M}$.

Vascular supporting cells. Evidence for high affinity MSA receptors was also found in aortic smooth muscle cells and retinal capillary pericytes. Specific binding of ${ }^{125} \mathrm{I}-\mathrm{MSA}$ in the smooth muscle cells was at least $7.8 \%$ per milligram (Fig. 5 A), and it was $5.6 \%$ in the pericytes (Fig. 5 B). $1-1.5 \times 10^{-8}$ M MSA displaced $50 \%$ of the specifically bound ${ }^{125}$ I-MSA in both types of cells, and in neither type did insulin cause any displacement, even at $10^{-7} \mathrm{M}$ for the smooth muscle and $10^{-6}$ $\mathbf{M}$ for the pericytes. Scatchard analysis yielded straight line plots, as illustrated in Fig. $2 \mathrm{~B}$, for both the smooth muscle cells and pericytes, and the $K_{\mathrm{d}}$ values were calculated to be $1.9 \times 10^{-8} \mathrm{M}^{-1}$ and $1.2 \times 10^{-8} \mathrm{M}^{-1}$, respectively.

Effect of insulin, IGF-I, MSA, and growth hormone on DNA synthesis in vascular cells

The effect of insulin, IGF-I, and MSA on $\left[{ }^{3} \mathrm{H}\right]$ thymidine incorporation into DNA was measured in all four cell types (Table II). In retinal capillary endothelial cells, all three hormones stimulated $\left[{ }^{3} \mathrm{H}\right]$ thymidine incorporation two- to
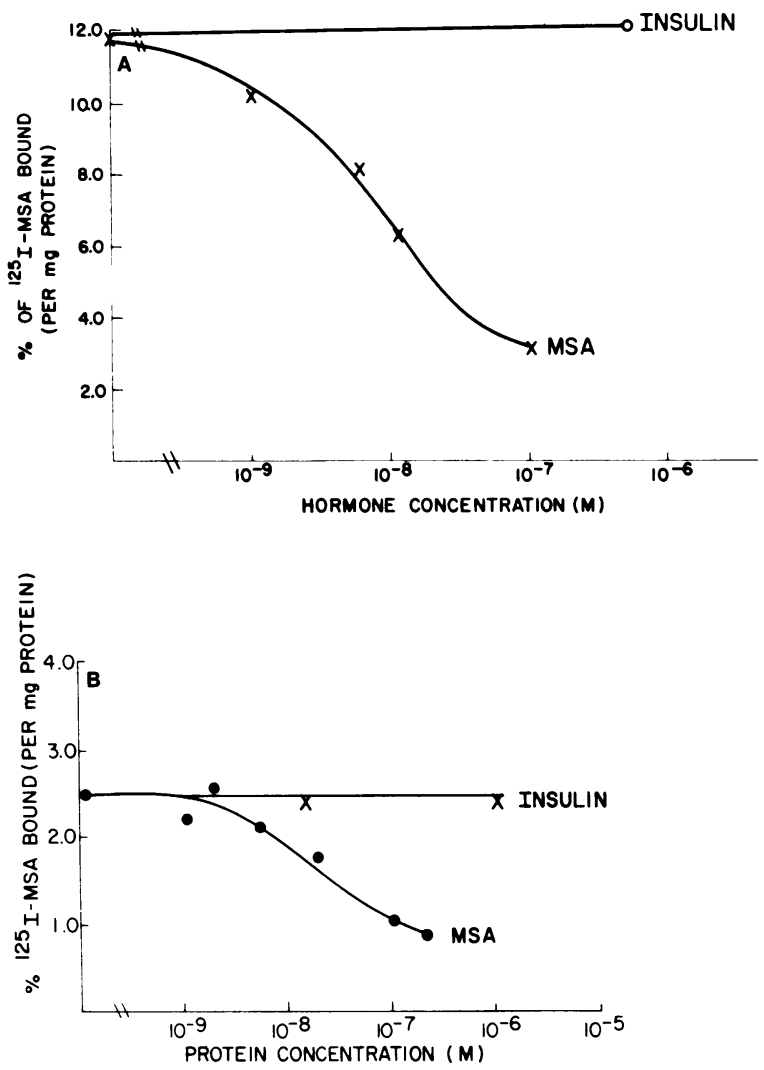

Figure 4. Inhibition of ${ }^{125}$ I-MSA binding to $(A)$ aortic endothelial cells and $(B)$ retinal capillary endothelial cells by unlabeled MSA and insulin. Each point is the average of duplicates in one experiment.

threefold (Fig. 6). Insulin appeared to be more potent than IGF-I or MSA. Some stimulation of DNA synthesis was observed with $3 \times 10^{-9} \mathrm{M}$, half-maximal at $1 \times 10^{-8} \mathrm{M}$, and the maximal effect occurred at $10^{-7} \mathrm{M}$. IGF-I stimulated $\left[{ }^{3} \mathrm{H}\right]$ thymidine incorporation starting at $5 \times 10^{-9} \mathrm{M}$, halfmaximal stimulation was at $3 \times 10^{-8}$, and the maximal effect was reached at $5 \times 10^{-8} \mathrm{M}$. The dose-response curves of IGFI and insulin were strikingly different in their shape. The IGF dose-response curve occurred over a very narrow range (5 $\times 10^{-9} \mathrm{M}$ to $5 \times 10^{-8} \mathrm{M}$ ), whereas insulin's range was quite broad $\left(3 \times 10^{-9} \mathrm{M}\right.$ to $\left.2 \times 10^{-7} \mathrm{M}\right)$. MSA was the least potent of the three hormones for stimulation of DNA synthesis, requiring $5 \times 10^{-8} \mathrm{M}$ for minimally effective and $10^{-7} \mathrm{M}$ for maximal effect. Addition of maximal effect concentrations of insulin and the IGFs (IGF-I and MSA) resulted in no additional effect, suggesting these hormones are stimulating DNA synthesis through the same pathway (Fig. $7 \mathrm{~A}$ ). The addition of suboptimal concentrations of insulin $\left(1.7 \times 10^{-8} \mathrm{M}\right)$ and IGFs $(1.5$ $\left.\times 10^{-8} \mathrm{M}\right)$ were additive, however. Insulin $\left(1.7 \times 10^{-6} \mathrm{M}\right)$, IGF-I $\left(5 \times 10^{-8}\right)$, and MSA $\left(10^{-7} \mathrm{M}\right)$ also increased the percentage of nuclei incorporating $\left[{ }^{3} \mathrm{H}\right]$ thymidine for $8-20 \%$ (data not shown).

Endothelial cells from bovine aorta were not responsive to insulin $\left(1 \times 10^{-6} \mathrm{M}\right)$ or the IGFs $\left(1 \times 10^{-8} \mathrm{M}\right)$ in the confluent state (data not shown), but the $\left[{ }^{3} \mathrm{H}\right]$ thymidine incorporation was increased by $40 \%$ in the nonconfluent growing state when insulin, IGF-I, or MSA was added at $1 \times 10^{-6} \mathrm{M}, 1 \times 10^{-8}$ $\mathrm{M}$, or $1 \times 10^{-7} \mathrm{M}$, respectively (Fig. 8 ). The increase was much less than that observed in the retinal capillary endothelial cells. When aortic endothelial cells passaged and grown in 

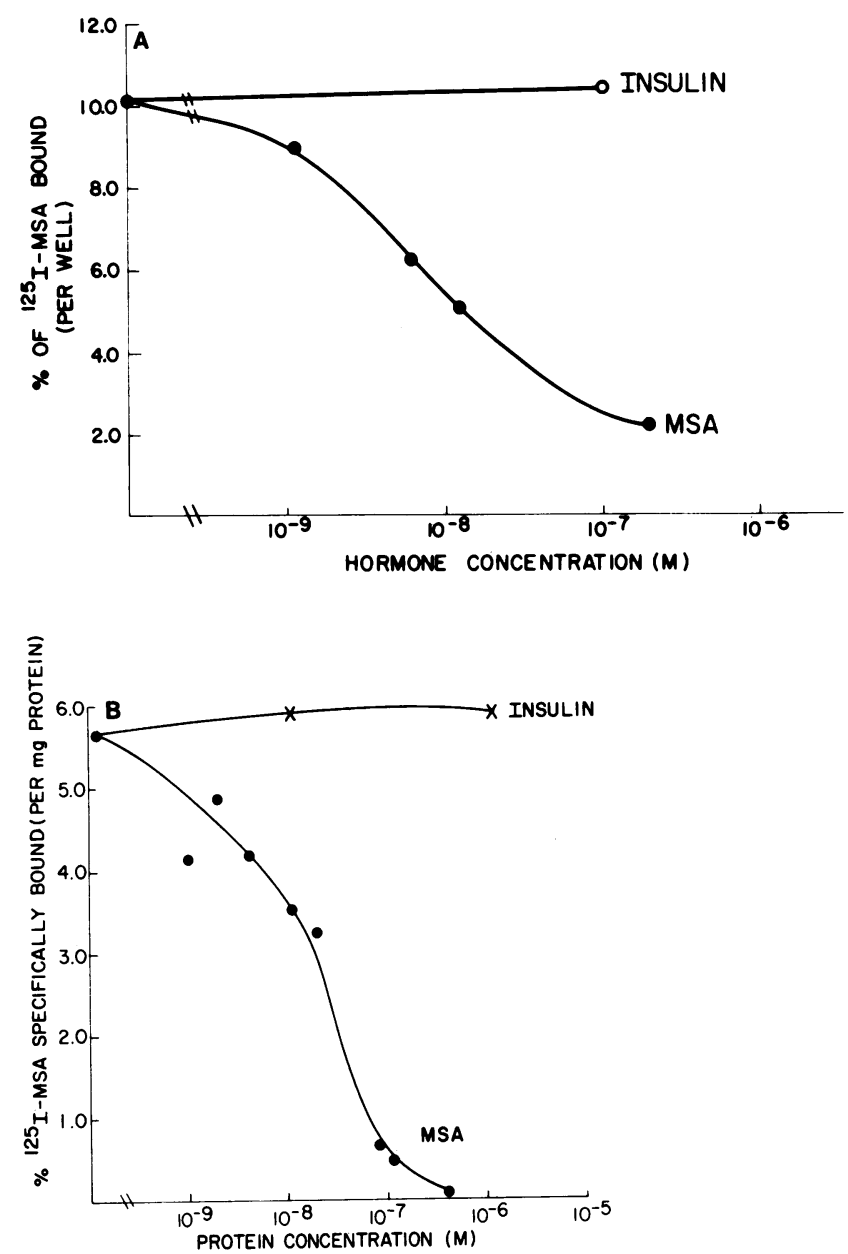

Figure 5. Inhibition of ${ }^{125} \mathrm{I}$-MSA binding to $(A)$ aortic smooth muscle cells and $(B)$ retinal capillary pericytes by unlabeled MSA and insulin. The data shown are for one of two similar experiments. Each point is the average of duplicates in one experiment.

sarcoma-conditioned media as the retinal endothelial cells, it was still not very responsive to insulin or IGF-I (Table III).

All three hormones stimulated $\left[{ }^{3} \mathrm{H}\right]$ thymidine incorporation into DNA in vascular supporting cells. As we have reported previously (7), insulin produced some stimulation of $\left[{ }^{3} \mathrm{H}\right]$ thymidine incorporation into retinal capillary pericytes at

Table II. Effect of Serum, Insulin, and Growth Hormone on DNA Synthesis of Various Types of Cells

\begin{tabular}{|c|c|c|c|}
\hline \multirow[b]{2}{*}{ Cells } & \multicolumn{3}{|c|}{$\left[{ }^{3} \mathrm{H}\right]$ Thymidine incorporation (\% of basal) by } \\
\hline & $\begin{array}{l}\text { Serum } \\
(10 \%)\end{array}$ & $\begin{array}{l}\text { Insulin } \\
\left(1.7 \times 10^{-6} \mathrm{M}\right)\end{array}$ & $\begin{array}{l}\text { Growth hormone } \\
(200 \mathrm{ng} / \mathrm{ml})\end{array}$ \\
\hline \multicolumn{4}{|l|}{ *Aortic } \\
\hline Endothelial cells & $42 \% \ddagger$ & $10 \%$ & $-3 \%$ \\
\hline Smooth muscle cells & $1,150 \%$ & $240 \%$ & $-4 \%$ \\
\hline \multicolumn{4}{|l|}{${ }^{*}$ Retinal capillary } \\
\hline Endothelial cells & $310 \%$ & $260 \%$ & $5 \%$ \\
\hline Pericytes & $960 \%$ & $640 \%$ & $2 \%$ \\
\hline
\end{tabular}

* Near-confluent cells on six-well dishes were used for these studies. \# The values are the average of two experiments.

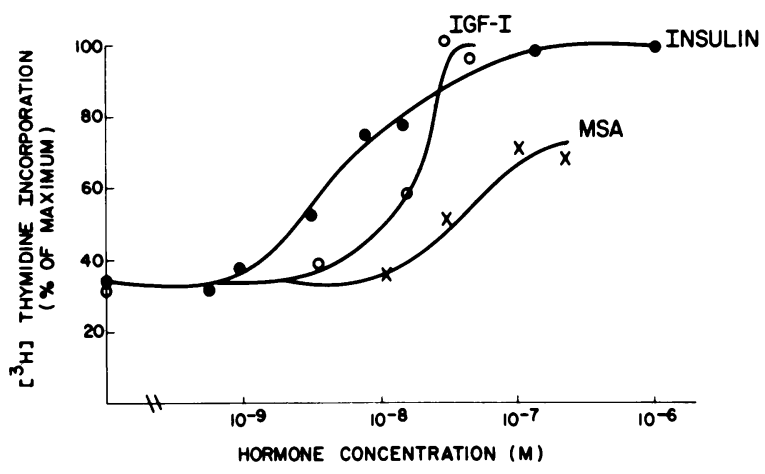

Figure 6. Effect of insulin (๑), IGF-I (o), and MSA $(X)$ on $\left[{ }^{3} \mathrm{H}\right]$ thymidine incorporation into DNA of retinal capillary endothelial cells. Each point is the average of triplicate wells in each experiment. Almost confluent cultures were exposed to these growth factors for $16-20 \mathrm{~h}$ at $37^{\circ} \mathrm{C}$ and then labeled with $\left[{ }^{3} \mathrm{H}\right]$ thymidine for 30 min. Detailed description of the insulin study was reported earlier (7).

$1 \times 10^{-9} \mathrm{M}$, and stimulation reached a maximum at $1 \times 10^{-7}$ $M$ with a 6-7-fold increase above basal (Fig. 9). IGF-I produced a significant increase in DNA synthesis beginning at $1 \times 10^{-9}$ $M$ and caused a probable maximum response at $5 \times 10^{-8} \mathrm{M}$. MSA was 10-fold less potent than IGF-I or insulin. The maximal level of stimulation was probably the same for both IGF-I and insulin since the addition of $5 \times 10^{-8} \mathrm{M}$ IGF-I and $1 \times 10^{-6} \mathrm{M}$ insulin was no more effective than either the IGFI or the insulin alone (Fig. $7 \mathrm{~B}$ ). Similar to the retinal endothelial cells, the dose-response curve of insulin differed from that of the IGFs by extending over a very broad range of concentration $\left(10^{-10} \mathrm{M}-10^{-7} \mathrm{M}\right)$. Again, with the combination of suboptimal concentrations of insulin $\left(1.6 \times 10^{-8} \mathrm{M}\right)$ and IGF-I $\left(5 \times 10^{-9} \mathrm{M}\right)$, an additive response was observed (Fig. 7 B). In addition to stimulation of DNA synthesis, insulin at $1 \times 10^{-6} \mathrm{M}$ increased the cell number of the pericytes by 1.9-fold above basal conditions (Table IV), and $10 \%$ calf serum increased the number of pericytes by 3.5 -fold.

Aortic smooth muscle cells (in the presence of $0.5 \%$ serum) responded to insulin, IGF-I, and MSA to the same maximum level (Fig. 10). Unlike retinal capillary endothelial cells, IGF-I was more potent than insulin and MSA by 10 - to 100 -fold. Maximum stimulation of $\left[{ }^{3} \mathrm{H}\right]$ thymidine was apparently achieved with $1 \times 10^{-8} \mathrm{M}$ IGF-I, whereas for comparable effects, $1 \times 10^{-6} \mathrm{M}$ of insulin and $1 \times 10^{-7} \mathrm{M}$ MSA were needed. As in other cells, the combination of insulin with either IGF-I and MSA at high concentrations was not additive. However, at lower, near-physiological concentrations, insulin and IGF-I or MSA had additive effects (Fig. 10). Compared to the growth effect of $10 \%$ bovine serum, insulin and IGF's maximum were approximately half as potent.

Insulin and IGF-I stimulated an increase of the number of aortic smooth muscle cells as well. At concentrations of 1 $\times 10^{-7}$ and $1 \times 10^{-6} \mathrm{M}$, insulin increased the number of cells by 35 and $51 \%$, respectively above the basal level. IGF-I at 1 $\times 10^{-8} \mathrm{M}$ also increased the number of cells by $40 \% .10 \%$ serum in comparison was more potent than insulin or IGF-I and stimulated an increase of 2.4-fold (Table IV).

Lastly, bovine growth hormone at concentrations of 25 and $200 \mathrm{ng} / \mathrm{ml}$ did not increase the rate of $\left[{ }^{3} \mathrm{H}\right]$ thymidine incorporation into the DNA of endothelial cells of retinal 

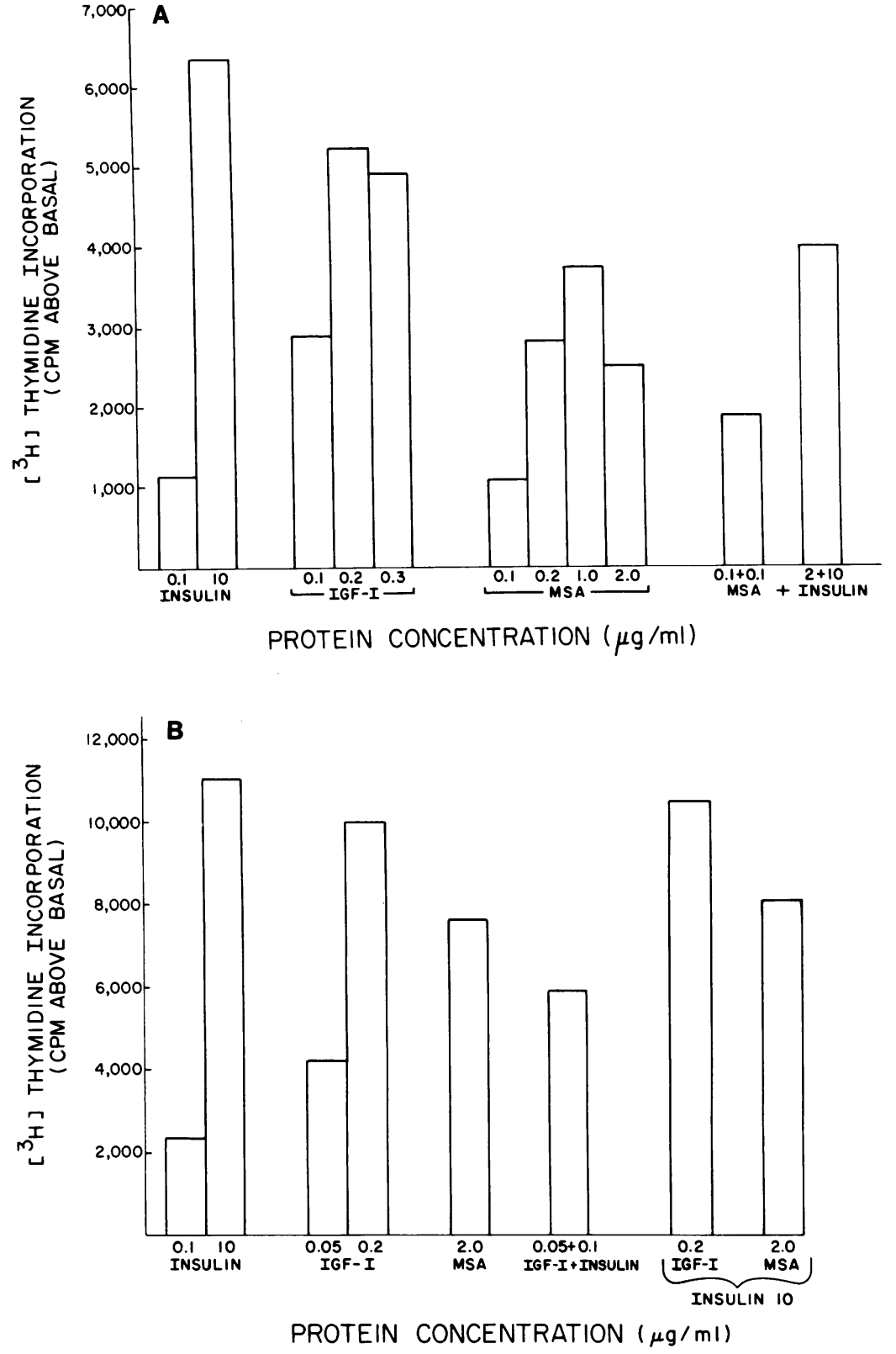

Figure 7. Effect of the combination of insulin and IGFs on $\left[{ }^{3} \mathrm{H}\right]$ thymidine incorporation into DNA of $(A)$ retinal capillary endothelial cells and $(B)$ pericytes. Insulin and IGFs were added at the same time, and the cultures were incubated for $16-20 \mathrm{~h}$ at $37^{\circ} \mathrm{C}$ before being labeled with $\left[{ }^{3} \mathrm{H}\right]$ thymidine for $30 \mathrm{~min}$. Other experimental details are described in Methods.

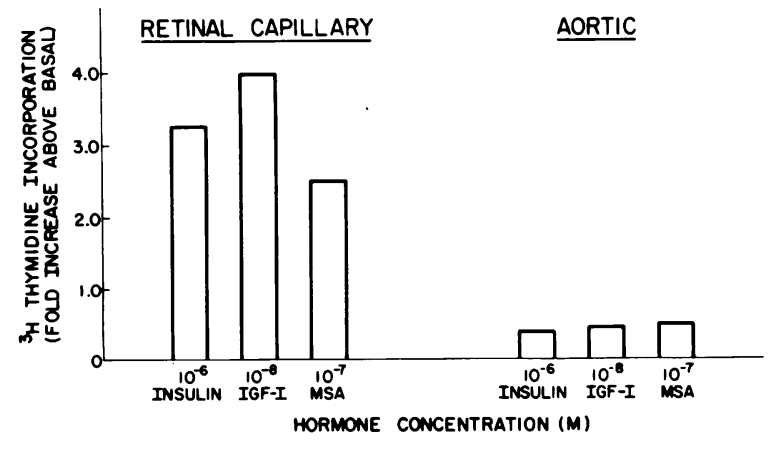

Figure 8. Comparison of the stimulating effect of insulin, IGF-I, and MSA on DNA synthesis incorporation in endothelial cells from bovine retinal capillaries (left) and aorta (right). Confluent retinal endothelial cells and nonconfluent aortic endothelial cells were used. The results are the means of four points and results varied $<15 \%$. Procedures for the thymidine assays are described in Methods. capillaries and aorta and vascular supporting cells of retinal pericytes and aortic smooth muscle cells (Table II).

\section{Discussion}

The data presented have documented specific receptors for IGF-I and MSA (an IGF-II) on bovine retinal capillary pericytes and endothelial cells, and on aortic endothelial and smooth muscle cells. All four cell types possess IGF-I and II receptors that are similar to those reported previously in other cells with respect to affinity and numbers $(19,20)$. Both insulin and MSA are able to bind to the IGF-I receptor with an affinity $\sim 1-10 \%$ that of IGF-I. In contrast, MSA (IGF-II) receptors exhibit a higher degree of specificity, with insulin producing little competition for binding even at very high concentrations. This difference in specificity has been confirmed by affinity cross-linking the ${ }^{125}$ I peptide hormones to their respective 
Table III. Effect of Different Growth Media on the Responsiveness of Aortic Endothelial Cells to Insulin and IGF-I

\begin{tabular}{|c|c|c|}
\hline & \multicolumn{2}{|c|}{ Stimulation of $\left[{ }^{3} \mathrm{H}\right]$ thymidine incorporation } \\
\hline & \multicolumn{2}{|c|}{ Aortic endothelial cells grown in: } \\
\hline & ${ }^{*} \mathrm{DMEM}$ & $\begin{array}{l}\text { *Sarcoma-conditioned } \\
\text { media }\end{array}$ \\
\hline Basal & 4,265 & 4,726 \\
\hline Insulin $\left(1.7 \times 10^{-7} \mathrm{M}\right)$ & 5,329 & 4,710 \\
\hline$\left(1.7 \times 10^{-6} \mathrm{M}\right)$ & 4,708 & 4,936 \\
\hline IGF-I $\left(2 \times 10^{-8} \mathrm{M}\right)$ & 4,917 & 4,765 \\
\hline Serum ( $10 \%$ calf serum) & 6,048 & 6,155 \\
\hline
\end{tabular}

* The procedures for growing of cells in DMEM have been described in the Methods section. For the cells in the sarcoma-conditioned media, aortic endothelial cells were passaged two times in the sarcomaconditioned media and grown to near-confluent level before they were placed in media containing $0.5 \%$ calf serum as described in Methods. The values were the average of triplicate assays.

receptors and identification by polyacrylamide electrophoresis and autoradiography (submitted elsewhere). Bar et al. (21) have also shown that insulin does not bind to the MSA receptor in bovine aortic endothelial cells.

The endothelial cells from the retinal capillaries bound less MSA than did aortic endothelial cells. The difference is due to a receptor number decrease rather than a decrease in the binding affinity as suggested by Scatchard analysis. Scatchard analysis showed straight lines for IGF-I and MSA receptors, suggesting that each consist of a homogeneous, noninteracting population of receptors. This differs from insulin receptors on these cells which we reported previously to have curvilinear Scatchard plots (7).

Although these endothelial cells from micro- and macrovessels have IGF receptors with similar binding characteristics, they do not respond equally to IGF-I and MSA with regard to growth-promoting effects. Retinal capillary endothelial cells exhibit a good response to IGFs and insulin in terms of $\left[{ }^{3} \mathrm{H}\right]$ thymidine incorporation into DNA, while aortic endothelial cells were not very responsive (Fig. 9). This differential responsiveness to IGFs is consistent with our previous study in which we showed that these cells had a similar response to insulin

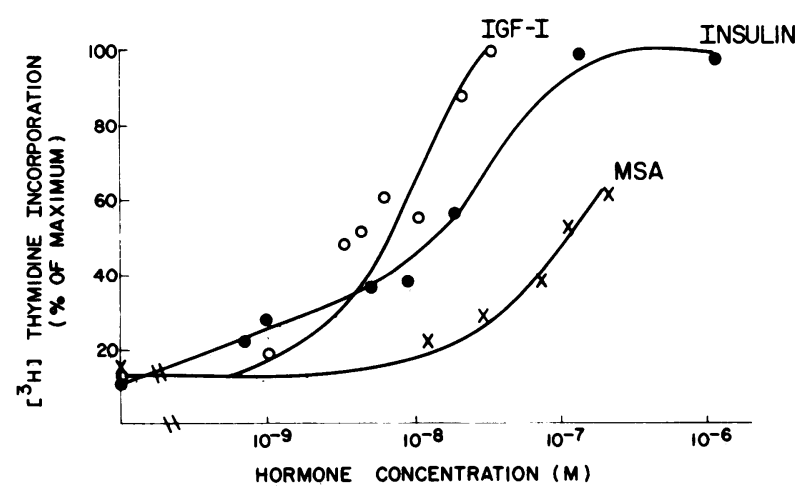

Figure 9. Effect of insulin (๑), IGF-I, and MSA $(X)$ on $\left[{ }^{3} \mathrm{H}\right]$ thymidine incorporation into DNA of retinal capillary pericytes. Experimental details are described in Fig. 6 and in Methods.
Table IV. Effect of Insulin and IGF-I on the Growth of Vascular Supporting Cells

\begin{tabular}{lllr}
\hline Aortic smooth muscle cells & *Cell number $\left(1 \times 10^{3}\right.$ cells $\left./ \mathrm{ml}\right)$ & \\
\hline & & & \\
Culture conditions & 0 Days & 3 Days & 6 Days \\
Basal $(0.5 \%$ calf serum & 480 & 521 & 617 \\
$\quad+$ DMEM) & 480 & 588 & 825 \\
Basal + insulin $\left(1 \times 10^{-7} \mathrm{M}\right)$ & 480 & 681 & 930 \\
Basal + insulin $\left(1 \times 10^{-6} \mathrm{M}\right)$ & 480 & 676 & 849 \\
Basal + IGF-I $\left(2 \times 10^{-8} \mathrm{M}\right)$ & 480 & 761 & 1525 \\
Basal + 10\% calf serum & & & \\
& & & \\
Retinal Capillary Pericytes: & & & \\
Culture condition & 86 & 90 & 78 \\
Basal (2.5\% calf serum & 86 & 123 & 187 \\
$\quad+$ DMEM) & 86 & 183 & 303 \\
Basal + insulin $\left(1 \times 10^{-6} \mathrm{M}\right)$ & 86 & & \\
Basal + IGF-I $\left(2 \times 10^{-8} \mathrm{M}\right)$ & & & \\
Basal + 10\% calf serum & & & \\
\end{tabular}

* The cells were counted on a Coulter counter (Hialeah, FL). The values for cell number are the average of quadruplet assays. The cells were passaged and attached to the plates in the presence of $10 \%$ calf serum. The calf serum which was removed after $2 \mathrm{~h}$ was replaced with media as noted.

(7). It is possible that this difference could be due to the harvesting and the growth condition of these cells. This is unlikely since we have grown and passaged both types of endothelial cells in the same sarcoma media and the differential responses to insulin and IGFs persisted. However, we have not completely excluded the possibility that a subpopulation of insulin and IGF-responsive endothelial cells were isolated in the growth of retinal endothelial cells with sarcoma-conditioned media. Since the growth-promoting effects at high concentrations of insulin and IGFs are not additive, these polypeptide hormones are probably mediating their actions through the same pathway, if not the same receptors. Interestingly, the effects of IGF-I and insulin are additive when they are present in concentrations that are near physiological levels.

For the vascular supporting cells, no differential response to the IGFs growth effects was observed. Both retinal pericytes and aortic smooth muscle cells responded nicely to the IGFs as well as to insulin as shown previously (7). The narrow doseresponse curves of the IGF-I suggests that its growth-promoting effect is mediated only via its own receptors (Fig. 6). In pericytes, insulin can bind both to its own receptors at high affinity (7) and to IGF-I receptors at low affinity (Fig. 3 B). Thus, insulin may stimulate growth in the pericytes through both receptors, and this may account for the broad doseresponse curve. As in the retinal capillary endothelial cells, insulin and IGFs are probably mediating their effects via a similar pathway since no additivity was seen when they are present together at high concentrations. Again, however, at near-physiological levels, insulin and IGF-I were additive in their effects. Unlike insulin and IGFs, growth hormone did not have any effect, suggesting that its possible physiological effects on the vascular cells are mediated through the IGF.

The physiological significance of the growth-promoting effects of insulin and IGFs are not clear, since the effects of these growth factors were assayed in virtual absence of other known serum growth factors. Furthermore, most of the data are based on thymidine incorporation which only indicates an 


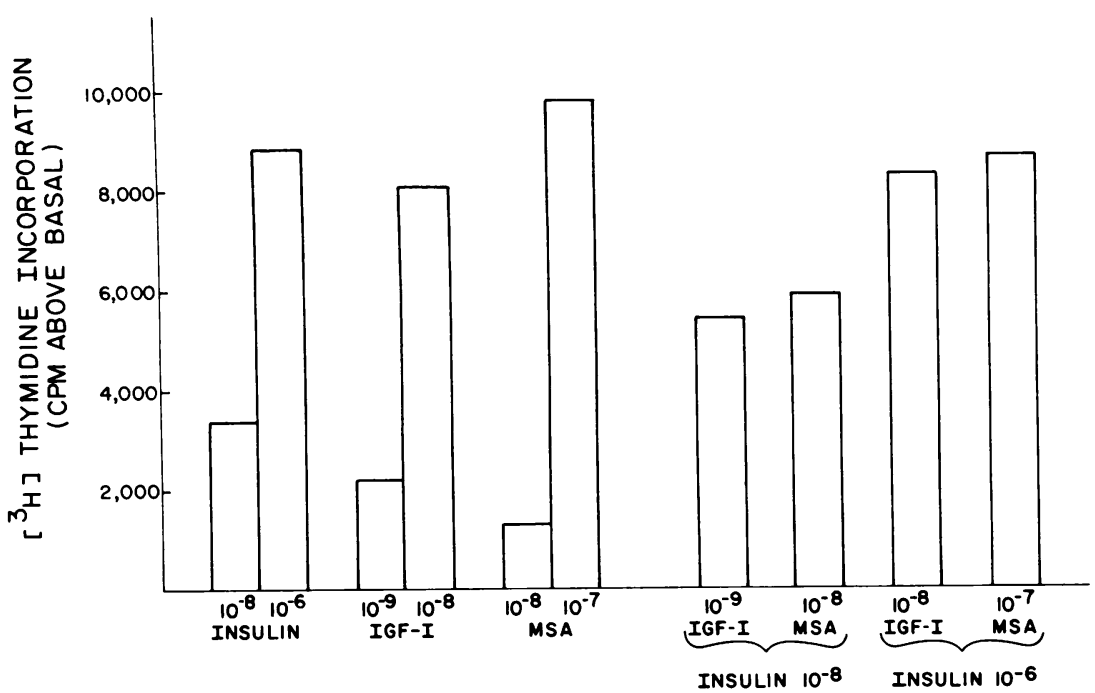

PROTEIN CONCENTRATION (M)
Figure 10. Effect of insulin, IGF-I, and MSA on thymidine incorporation in aortic smooth muscle cells. The mean and the standard error values were derived from quadruple assays on confluent cultures. Procedures for the thymidine assays are described in Methods. increase in DNA synthesis and not necessarily cell number increase since changes in $\left[{ }^{3} \mathrm{H}\right]$ thymidine pool sizes or in the specific activity of deoxythymidine triphosphate could lead to problems of interpretation. For the pericytes and aortic smooth muscle cells, these growth factors increased the number of cells as well, thus confirming the growth effects of insulin and IGFs. Further, these studies were performed in the virtual absence of other growth factors. Thus, the dose-response curve could probably be altered when other growth factors are added.

The finding of differential responsiveness to insulin and IGFs may be important in the histopathological differences observed in diabetic retinopathy and peripheral macroangiopathy. Both of these vascular complications of diabetes have in common the feature of cellular proliferation as a part of the pathologic process, although different cells are involved: endothelial cells proliferating in retinopathy (2) and smooth muscle cells in peripheral macroangiopathy (22). Our data would suggest that elevations of insulin and IGF-I which may occur during intensive insulin treatment $(23,24)$ could accelerate proliferation of retinal capillaries. Clinical evidence is available to support this hypothesis. Daneman et al. have found that diabetic patients with Mauriac syndrome developed worsening retinopathy after intensified insulin treatment (25).

For macroangiopathy, no endothelial cell proliferation is observed, although arterial endothelial cells are exposed to similar levels of insulin and IGF-I, possibly because the proliferation of the arterial endothelial cells is controlled differently, as documented by their unresponsiveness to insulin and IGFs. However, arterial smooth muscle cells are responsive to both insulin and IGFs, and their effects are additive at near physiological concentrations. Thus, hyperinsulinemia in combination with an elevation in IGF-I could accelerate the proliferation of vascular smooth muscle cells and thus aggravate the ongoing process of atherosclerosis. Clinically, peripheral vascular complications occur more frequently in non-insulindependent diabetic patients who often have more hyperinsulinema $(26,27)$, and hyperinsulinema also has been shown to correlate with the occurrence of atherosclerosis $(27,28)$. Although the IGF values in type II diabetic patients are not elevated (6), studies are needed to determine if there is a correlation between the level of the IGFs and the presence of atherosclerosis. These data suggest that insulin and IGFs may have a role in the development of diabetic vascular complications.

\section{Acknowledgment}

The authors wish to express their appreciation for the technical assistance of Sherry Buchwald and Nancy Hetu, and the secretarial help of Patricia Morrison and Barbara Cornell.

The studies were funded by a grant from the Juvenile Diabetes Foundation and National Institutes of Health grants EY05110 and EY03515.

\section{References}

1. Caird, F. I., A. F. Burditt, and G. J. Draper. 1968. Diabetic retinopathy: a further study of prognosis for vision. Diabetes. 17:121123.

2. Patz, A. 1980. Studies on retinal neovascularization. Invest. Ophthalmol. Vis. Sci. 19(10):1133-1138.

3. Kohner, E. M., A. M. Hamilton, G. F. Joblin, and T. R. Fraser. 1976. Florid diabetic retinopathy and its response to treatment by photocoagulation on pituitary ablation. Diabetes. 25:104-110.

4. Merimee, J. J., J. Zapf, and F. R. Froesch. 1983. Insulin-like growth factors: Studies on diabetes with and without retinopathy. $N$. Engl. J. Med. 309:527-530.

5. Merimee, J. J. 1978. A follow-up study of vascular disease in growth-hormone deficient dwarfs with diabetes. N. Engl. J. Med. 298: $1217-1222$.

6. Lamberton, R. P., A. D. Goodman, A. Kassoff, C. L. Rubin, D. H. Treble, T. M. Saba, J. J. Merimee, and W. J. Dudds. 1984. Von wille brand factor (VIII) fibronectin and insulin-like growth factors I and II in diabetic retinopathy and nephropathy. Diabetes 35:125-129.

7. King, G. L., S. M. Buzney, C. R. Kahn, N. Hetu, S. Buchwald, S. G. MacDonald, and L. I. Rand. 1983. Differential responsiveness to insulin of endothelial and support cells from micro- and macrovessels. J. Clin. Invest. 71:974-979.

8. Renderknecht, E., and R. E. Humbel. 1978. The amino acid sequence of human insulin-like growth factor I and its structural homology with proinsulin. J. Biol. Chem. 253:2769-2775.

9. Moses, A. C., S. P. Nissley, P. A. Short, M. M. Rechler, and J. M. Podskalny. 1980. Purification and characterization of Multiplication Stimulating Activity (MSA) insulin-like growth factor purified from rat liver cell condition media. Eur. J. Biochem. 103:387-400.

10. Grigorescu, F., M. White, and C. R. Kahn. 1983. Insulin binding and insulin-dependent phosphorylation of the insulin receptor 
solubilized from human erythrocytes. J. Biol. Chem. 258:1370813716.

11. Glieman, J., O. Sonne, S. Linde, and B. Hansen. 1979. Biological potency and binding affinity of monoiodoinsulin with iodine in tyrosine A-14 or tyrosin A-19. Biochem. Biophys. Res. Commun. 87:1183-1190.

12. Buzney, S. M., and S. J. Massicotti. 1979. Retinal vessel proliferation of endothelium in vitro. Invest. Ophthalmol. Vis. Sci. 18: 1191-1195.

13. Folkman, J., C. C. Hauderschild, and B. R. Zetter. 1979. Longterm culture of capillary endothelial cells. Proc. Natl. Acad. Sci. USA. 76:5217-5221.

14. Gimbrone, M. A., and R. S. Cotran. 1975. Human vascular smooth muscle in culture. Growth and ultra structure. Lab. Invest. 33:16-20.

15. Rechler, M. M., J. M. Podskalny, I. D. Goldfine, and C. A. Wells. 1974. DNA synthesis in human fibroblasts: stimulation by insulin and by non-suppressible insulin-like activity (NSILA-S). $J$. Clin. Endocrinol. Metab. 39:512-521.

16. King, G. L., C. R. Kahn, M. M. Rechler, and S. P. Nissley. 1980. Direct demonstration of separate receptors for growth and metabolic activities of insulin and multiplication-stimulating activity (an insulin-like growth factor) using antibodies to the insulin receptor. J. Clin. Invest. 66:130-140.

17. Lowry, D. H., N. J. Rosebrough, A. L. Farr, and R. J. Randall. 1951. Protein measurements with the folin phenol reagents. J. Biol. Chem. 193:265-275.

18. Scatchard, G. 1974. The attraction of protein for small molecules and ions. Ann. NY Acad. Sci. 51:660-672.

19. Zapfs, J., E. Schoenle, and E. R. Froesch. 1978. Insulin-like growth factors I and II: some biological actions and receptor binding characteristics of two purified consistent of non-suppressible insulinlike activity of human serum. Eur. J. Biochem. 87:285-296.

20. Rechler, M. M. 1980. Receptors for somotomedian and related peptides. In Diabetes. W. K. Waldhoues, editor. Excerpta Medica, Amsterdam. 266-271.

21. Bar, R. S., M. L. Peacock, M. M. Rechler, and S. P. Nissley. 1981. Receptors for multiplication stimulating activity on human arterial and venous endothelial cells. J. Clin. Endocrinol. Metab. 52: 814-816.

22. Ross, R., and L. Harber. 1976. Hyperlipidemia and atherosclerosis. Science (Wash. DC). 193:1094-1100.

23. Tamborlane, W. V., R. L. Hintz, M. Bergman, M. Genel, P. Felig, and R. J. Sherwin. 1981. Insulin-infusion-pump treatment of diabetes: influence of improved metabolic control on plasma somotomedian levels. $N$. Engl. J. Med. 305:303-307.

24. Hanna, A. K., B. Zinman, A. F. Nakhroda, H. L. Minak, E. F. Stokes, A. M. Albessis, B. S. Leibel, and E. B. Marless. 1980. Insulin, glucagon and amino acid during glycemic control by the artifical pancreas in diabetic man. Metab. Clin. Exp. 29:321-332.

25. Daneman, D., A. L. Drash, L. A. Lobes, D. J. Becker, L. M. Baker, and L. B. Travis. 1981. Progressive retinopathy with improved control in diabetic dwarfs (Mauriac Syndrome). Diabetes Care. 413: 360-365.

26. Nikkila, E. A., T. A. Miettinen, M. R. Vesenne, and R. Pelkmen. 1965. Plasma Insulin in Coronary Heart Disease. Lancet. II: 508-511.

27. Stout, R. M. 1977. The relationship of abnormal circulating insulin to atherosclerosis. Atherosclerosis. 27:1-13.

28. Stout, R. M., E. L. Burman, and R. Ross. 1975. Effect of insulin on the proliferation of cultured primate arterial smooth muscle cells. Circ. Res. 3(2):319-327. 